\title{
The Librarian in Catholic Institutions
}

\begin{abstract}
This paper attempts to examine the place of librarians in Catholic institutions of higher learning by providing answers to questions about the ratio of professional to nonprofessional staff, the presence or $a b$ sence of staff associations, the involvement of professional staffs in library administration through staff meetings, and the librarians' status and salaries. The search is based on a questionnaire, mailed to the head librarians of Catholic colleges and universities in the United States enrolling more than one thousand students. The necessary statistical data on the size of the libraries, the number of students they serve, and various standards applicable to the academic libraries were obtained from published sources. The paper presents, compares, and analyzes the data.
\end{abstract}

$\mathrm{T}$ HIS STUDY attempts to provide a profile of personnel practices in the Catholic colleges and universities in the United States. It reports such matters as participation of the librarian in staff meetings, the size of the student body he serves, his involvement in the library administration, and his remuneration in comparison with that of the teaching faculty. It is based primarily on a questionnaire mailed in the summer of 1966 to the library directors of institutions involved, but also on published statistical data. The questionnaire consisted of five parts. The first part examined the number of students enrolled during the academic year 1965-1966; the second part questioned the number of professional, subprofessional, ${ }^{1}$ clerical, and student assistant positions; and the remaining three parts dealt with such subjects as staff associations at the libraries, possible existence of staff meetings, value of

1 Subprofessional librarians, reported on the questionnaire in a few cases, are combined with professional librarians and are considered as such throughout the study.

Mr. Novak is Serials Librarian, University of Santa Clara, Santa Clara, California. meetings, and professional staff member's status and salary.

The selection of libraries to which the questionnaire was mailed was based on two sources. Institutions enrolling five hundred full-time students or more were chosen from the Catholic Colleges of the United States of America 1952-53 by Rev. James F. Whelan, S.J. The 1965 Official Guide to Catholic Educational Institutions (hereafter called the Official Guide) was used for selection of colleges and universities with enrollments of one thousand students and more. The Official Guide was also utilized for comparison of growth in enrollment in colleges selected from Father Whelan's source. Colleges where the enrollment during the intervening years had not reached the figure of approximately one thousand full-time students were dropped from the list.

The resulting list consisted of seventy colleges and universities. This represented 33 per cent of 211 Catholic institutions of higher learning in the United States listed in the Official Guide. Of the seventy library directors, thirty-one were directing university libraries, and thirty-nine were managing college li- 
braries. Twenty university librarians and thirty-six college librarians filled out and returned the questionnaire. These fiftysix libraries, which are the subject of this study, represent 26 per cent of all four-year colleges and universities listed in the Official Guide, or 80 per cent of all Catholic institutions of higher learning in the United States with enrollments of one thousand students or more.

\section{Review of FifTy-six Libraries}

In order to assess properly the information in the subsequent paragraphs, a brief preliminary review of the fifty-six libraries involved in the study may be given. Of these libraries, forty serve student bodies of from 1,000 to $2,500 \mathrm{stu}-$ dents, eight have student bodies of up to 7,000 students, and the remaining eight university libraries serve 7,001 to 13,000 students. Their book collections range from a book stock of 35,000 volumes to an impressive 650,000 volumes. The same numerical diversity is noticed in their current periodical subscriptions, ranging from 280 to 4,540 titles. The total number of staff administering these collections ranges from 3 to 127 persons, and the range of professional staff extends from 2 to 37 librarians. The percentage of professional personnel in relation to the total number of staff also varies. As little as 9 per cent of the staff represents the professional group in one library, but on the other end of the range, 61 per cent of the staff is professional.

Some of the above statements require a closer look and additional analysis. Regarding the book stock, twelve libraries, of fifty-five for which the figures were available, hold between 35,000 and 52,000 volumes; twenty libraries have 53,000 to 99,000 books; thirteen claim 100,000 to 200,000 volumes; and eleven own more than 200,000 volumes. While all of the libraries meet today the archaic 1931 American Library Association standards ${ }^{2}$ holding that a collection of 14,000 volumes is satisfactory for a fouryear college, several do not meet the newer ALA (1947) standards ${ }^{3}$ requiring

${ }^{2}$ Charles B. Shaw, List of Books for College Libraries (Chicago: ALA, 1931).

${ }^{3}$ Classification and Pay Plans for Libraries in Institutions of Higher Education (2d ed., Chicago: ALA, 1947 ), II, 2.

TABLE 1. 56 Catholic College and University Libraries*

\begin{tabular}{|c|c|c|c|}
\hline & \multicolumn{3}{|c|}{$\begin{array}{c}\text { STUdent ENROLlMENT } \\
\text { (Full-time Equivalent) }\end{array}$} \\
\hline & $1,000-2,500$ & $2,501-7,000$ & $7,001-13,000$ \\
\hline $\begin{array}{l}\text { Number of institutions } \\
\text { Range in book holdings } \\
\text { Range in number of periodical titles received } \\
\text { Range in number of total staff, including } \\
\text { students ( full-time equivalent) } \\
\text { Range in number of total staff, excluding } \\
\text { student help } \\
\text { Range in number of total professional staff } \\
\text { Range in percentage of professional staff } \\
\text { Range in percentage of professional staff, } \\
\text { excluding student help } \\
\text { Number of institutions having following } \\
\text { percentage of professional staff: } \\
9-20 \% \\
21-30 \% \\
31-40 \% \\
41-61 \% \\
.\end{array}$ & $\begin{array}{l}40 \\
35,000-178,000 \\
280-1,457 \\
3-48 \\
3-13 \\
3-9 \\
10-61 \\
33-100 \\
\\
18 \\
9 \\
7 \\
5\end{array}$ & $\begin{array}{c}8 \\
63,000-650,000 \\
325-4,540 \\
10-127 \\
6-77 \\
2-37 \\
9-37 \\
28-66\end{array}$ & $\begin{array}{c}8 \\
154,000-621,000 \\
1,450-3,284 \\
53-100 \\
24-71 \\
12-26 \\
16-40 \\
35-60\end{array}$ \\
\hline
\end{tabular}

- Student enrollment figures and information on staffs are based on the questionnaire sent to librarians of these institutions. Book holdings and periodical titles received are taken from The Official Guide to Catholic Educational Institutions, 1965. 
a mininum collection of 40,000 volumes. The most recent ALA selection guide, ${ }^{4}$ calling for a minimum of 53,000 titles for an institution granting a four-year degree, is not met by a dozen libraries. It is to be noted that this 1967 guide indicates the minimum number of titles; the number 53,000 would certainly be increased if it were translated into volumes. Some of the libraries, on the other hand, exemplify a remarkable degree of achievement in book collection development considering the difficulty in obtaining adequate funds. The number of periodicals subscribed to by the institutions also varies greatly. Of fifty-five libraries in the tabulation, thirty receive fewer than six hundred periodical titles, and twentyfive get between 604 and 4,540 titles regularly. There are no ALA minimum standards available for a desired size of periodical collections or number of periodical subscriptions, but the Classified List of Periodicals for the College Library by Ira E. Farber (4th edition) lists 601 periodical titles for college libraries.

The number of students per librarian represents another interesting field for comparison (see Tables 2 and 3 ). In the smaller libraries, with the enrollment of 100 to 2,500 students, the median number of students per librarian is 286 , ranging in different schools from 93 to 713 students per professional librarian. In college libraries serving over 2,500 students, the librarian-student ratio ranges from 1 librarian to 167 students up to 1 librarian to 1,380 students, with the median at 506 students per librarian. The median for the librarian-student ratio for all libraries in the study is 1 to 330.

\footnotetext{
4Books for College Libraries: A Selected List of Approximately 53,400 Titles Based on the Initial Selection Made from the University of California's New Campus Program and Selected with the Assistance of College Teachers, Librarians, and other Advisors, prepared under the direction of Melvin J. Voigt and Joseph H. Treyz (Chicago: ALA, 1967).
}

TABLE 2

Size of Total Staff in 56 Libraries

\begin{tabular}{l|c|c}
\hline \hline & \multicolumn{2}{|c}{ Number of } \\
\cline { 2 - 3 } & Libraries & Employees \\
\hline Serving 1,000-2,500 & 7 & $3-12$ \\
students & 11 & $15-20$ \\
& 14 & $21-30$ \\
Serving 2,501-13,000 & 8 & $31-48$ \\
students & 1 & 10 \\
& 6 & $21-30$ \\
& 6 & $53-66$ \\
& 3 & $90-127$ \\
\hline
\end{tabular}

- Full-time equivalent and including student assistants.

It must be realized that the method used above for securing a librarian-student ratio would be better replaced by the ALA's recommended method, which identifies a librarian's service in unit loads, but the use of such a system was impossible because unit loads are generally not readily available. The ALA method assigns one, two, three, four, and five units for each lower division undergraduate student, upper division undergraduate student, honors student, graduate student, and faculty, respectively. In order to indicate at least how this method works in the present situation, it will be applied to two libraries in this study by basing most of the missing data on the published sources, and employing some less important but necessary assumptions.

TABLE 3.

Size of Professional Staff in 56 Libraries

\begin{tabular}{c|c|c}
\hline \hline & \multicolumn{2}{|c}{ Number } \\
\cline { 2 - 3 } & Libraries & Professionals \\
\hline Serving 1,000-2,500 & 7 & 3 \\
students & 10 & 4 \\
& 11 & 5 \\
& 8 & 6 or 7 \\
Serving 2,501-13,000 & 4 & $8-11$ \\
students & 2 & 2 and 3 \\
& 4 & 5 or 6 \\
& 4 & $10-15$ \\
& 5 & $20-28$ \\
\hline
\end{tabular}

- Full-time equivalent and including student assistants. 
In the first example, library A has 1,215 undergraduate students and sixty faculty members, who are served by five professional librarians. Assuming that 500 of the students are upper division undergraduate students and the remainder are lower division undergraduates, the total service load for library A would be 2,015 units. This number of units places the library in Class 3-College Libraries-of the ALA's Classification and Pay Plans (to which the majority of colleges in this study belong). According to these minimum standards, library A should be staffed by a chief librarian and three professional assistants for the first 800 units, and one more professional librarian for each additional 500 units or fraction thereof, or a total of six and onehalf professional staff members. In the second example, library B has 6,100 students, 1,000 in the graduate program and 5,000 in the undergraduate schools, and 480 teachers, who are served by thirty-seven librarians. The total service load for this university library would be 13,500 units, which would place it in the Class 6-University Libraries-of the ALA's Classification and Pay Plans. The University Libraries Class 6 requires, in addition to the position of the chief librarian, twenty-two assistants' positions of professional grade for 10,000 service units, and one more assistant's position of professional grade for each additional 500 units. According to this requirement, library $\mathrm{B}$ needs thirty professional librarians to satisfy the ALA's minimum standards.

The libraries in this study fall, by ALA classification, either in Class 3, Class 4, or Class 5 for four-year degree-granting institutions, or in one of the first six classes for the university libraries, as outlined in the Classification and Pay Plans. The minimum service load for the Class 3 libraries is 1,500 units, which requires four professional staff members. Table 3 reveals that there are nineteen libraries with fewer than five professional librar- ians, which is below the minimum standards. The larger libraries are, by comparison, staffed better, and some of them, as was shown in the case of library B, may even surpass the ALA's 1947 minimum standards.

Concerning the ratios of professional to nonprofessional personnel in libraries, one finds no generally accepted standards. The ALA proposal regarding such ratios was 40 to 60 per cent. ${ }^{5}$ Robert $B$. Downs concluded that "if more than one-third of the entire staff is composed of professionals, the probabilities are that they are performing a substantial amount of clerical routines and at the same time neglecting opportunities to assist readers in doing reference and research, to build up the resources of the library, and to carry on other distinctly professional work."6 But most of the libraries in this study favor nonprofessional staff which exceeds the professionalto-nonprofessional staff ratios of both proposals. While "the median for 140 libraries of private colleges with enrollments of one thousand or more is five professional to six and one-half nonprofessional, including student help in fulltime equivalent," fifty-six libraries, under the same conditions, ${ }^{8}$ is five professional to nineteen nonprofessional employees. Thus, of the fifty-six libraries under discussion, at twenty-three institutions the percentage of professional librarians on the staff is below 21 per cent; at fifteen libraries the percentage of professional librarians is 21 to 30 per cent; at twelve libraries

${ }^{5}$ Guy R. Lyle, The Administration of the College Library (3d ed., New York: The H. W. Wilson Co., 1961 ), p. 181

' Robert B. Downs, "The Place of College Librarian in the Academic World," California Librarian, XXVIII (April 1967), 103.

${ }^{7}$ Lyle, op. cit., p. 181.

8 When student assistance was reported in hours, 2,000 hours counted as one full-time employee. It is doubtful that the ratio of professional to nonprofessional staff could have changed so much during a period of five years. 
the trained librarians form 31 to 40 per cent of the staff; and at the remaining five libraries the range of the ratio of professional to nonprofessional personnel is 41 to 61 per cent of the total staff. It would appear that in the majority of fifty-six libraries in this study nonprofessional duties are delegated to those who can do the job cheaper and perhaps better, and that the professional librarian, hopefully, can be involved in more complex and rewarding areas of librarianship.

\section{Staff Associations}

Some of the libraries surveyed are large enough and employ a sufficient number of personnel to make a staff association feasible. But formal library staff associations exist at only three (4.2 per cent) institutions considered in the present survey. Two of the libraries with formal staff associations are among the largest ones in the study, but the third library, reporting an informal staff association, employs only ten people. None of the three library staff associations above publishes a newsletter, although of the fifty-six librarians who answered the questionnaire, two reported that a newsletter was published at their libraries. Another librarian indicated that his library "used to publish a 'log' but has discontinued it." One respondent replied that while there is no staff association at his institution, librarians nevertheless belong to the American Association of University Professors and other professional organizations.

\section{Staff Meetings}

Replies to questions on the subject of staff meetings are more varied and interesting. To the inquiry, "Do you hold staff meetings?" forty-six of the librarians (82 per cent) answered affirmatively. Regarding the frequency of such meetings, the following pattern emerges: eighteen head librarians ( 39 per cent) hold staff meetings monthly; at eleven libraries ( 24 per cent) the meetings are held two or three times a year; and ten institutions ( 22 per cent) hold staff meetings occasionally, irregularly, periodically, or when needed. Some libraries, on the other hand, have staff meetings more frequently. Four institutions ( 9 per cent) hold them three times per month; at two libraries ( 4 per cent) employees meet weekly; and at one library ( 2 per cent) the meetings are convened daily. Clarifying statements were added to some of the answers, such as "rarely hold a formal meeting"; "we discuss daily"; "monthly, have coffee together daily"; "once a month and whenever need arises"; "nominally once a month, actually less frequently"; "at least monthly; not often enough."

In answer to the inquiry concerning participation in staff meetings, the most frequent reply was that the library director and all professional staff take part in the discussions. Such is the case at twenty-six ( 56 per cent) of the surveyed libraries. All full-time personnel, professional and nonprofessional, meet at twelve ( 26 per cent) of the libraries. The directors of four ( 8 per cent) libraries report meetings held between the library director and the heads of all departments, and meetings between the library director and other professional members. The remaining four (6 per cent) respondents follow their own arrangement regarding staff meeting participants: director with professional staff, and director with clerical staff; director with professional, subprofessional, and some clerical staff; director with professional and subprofessional staff; and director with staff socially, director with heads of departments officially. There are some other arrangements, when at times clerical staff, and even the president of the college, also attend library staff meetings, or nonprofessional personnel is invited when needed for information. Some other comments are: "meetings with department heads are in- 
formal"; and "department heads also have meetings with their subordinates."

The replies to questions on the value of staff meetings indicate that the librarians are generally favorably inclined toward holding staff meetings. Thirtyseven (66 per cent) library directors answered affirmatively to the inquiry whether staff meetings help in decision making. That staff meetings furthermore improve library employee morale is obvious from the even higher percentage of affirmative answers, forty-one ( 73 per cent) stating agreement. The directors of forty-five ( 80 per cent) libraries thought that solutions to many library problems are ironed out at staff meetings. Additional questions examined the extent of staff participation in administration of the libraries involved: fortyfour (78 per cent) head librarians agreed that staff suggestions are listened to and that they influence policy decisions, while only two ( 3 per cent) head librarians agreed with the proposition that all policy decisions are made by the library director, and are not influenced but rather followed up by the staff.

In space provided some librarians include short comments on the preceding group of questions. Regarding "staff morale," one respondent said that his library has no problems. Another commented that solutions to library problems are not ironed out, but rather "solutions are begun to be found." Some policy decisions are influenced by the library committee, by the university Senate, by the academic vice president, or by a combination of the above bodies. One librarian commented on the power of the library committee, which consists of the librarian, who presides, and of all department heads and administration representatives. Harmony and teamwork are results of staff meetings, thought another library director: "It is our practice to point out various problems to the staff, have them discuss the problems, and through the discussion arrive at a solution, which is then issued if it affects users, or represented, in case it affects workers," was another comment. "We are able to discuss problems, so all will be informed"; "communications is probably the most important benefit of staff meetings"; and similar comments were expressed by several other librarians.

The final question regarding staff meetings tried to establish why they had been discontinued in a few libraries. A librarian with eight employees on his staff replied that formal meetings were discontinued because of the small size of staff. An intention to revive staff meetings, however, was planned by another library director who discontinued the meetings because of the small staff. The reason for discontinuation of official meetings in another library was the difficulty of getting personnel together. Individual conferences and person-to-person contact was found more effective by a respondent with twenty-four members on his staff.

\section{LIBRARIANs' Status and SALARIES}

The first issue in the questionnaire regarding librarians' status in college or university libraries examined the position of the head librarians. To the inquiry as to whether or not the library director holds the rank of dean, faculty rank, or other, five library directors ( 9 per cent) replied that they hold the rank of a dean or equivalent; forty-four (78 per cent) said they hold faculty rank; two ( 3 per cent) hold faculty status; and five ( 9 per cent) hold no rank. In thirty-nine libraries ( 70 per cent) librarians hold a faculty rank; seven ( 12 per cent) of college or university administrations give faculty status to librarians; and at nine (16 per cent) institutions librarians hold no rank. In reply to a query concerning when faculty rank was first given to librarians, this study established that at seven libraries the professional personnel held faculty recognition "always"; three institutions gave the librarians fac- 
ulty status in 1940's; twelve schools in the 1950 's; at nine institutions librarians obtained faculty status recognition in the 1960's; and one institution had recognized such status "for a long time."

The terms "faculty rank" and "faculty status" are often used, in the library literature, interchangeably. ${ }^{9}$ It is not unlikely that some of the respondents did the same. Thus it may be reasonable to assume that some of the thirty-nine directors reporting faculty rank for librarians meant it to be faculty status. By the same reasoning, it would seem wrong to assume that librarians at the nine institutions reporting no rank for the professional librarians were classified as clerks, but rather that they too most likely hold academic or faculty status. Be this as it may, if one adheres to the directors' replies and uses the terms "faculty rank" and "faculty status" interchangeably, one can record forty-six ( 82 per cent) institutions recognizing librarians as academic personnel.

By reviewing the faculty status of professional library personnel, it becomes evident that at seven institutions only the library director is given faculty status, to the exclusion of other professional librarians on the staff. Another university grants academic status to the director and also the heads of various library departments. The study further indicates that neither the size of the student body nor the number of professional librarians on the staff has any bearing on the academic status of librarians. At seven libraries, for example, where faculty rank is granted to library directors, the student body ranges from one thousand to ten thousand students, and the number of professional librarians from two to twenty-eight.

Only a few individual comments were given by the respondents in regard to faculty status. Some examples of these are: "faculty rank [is] not equivalent to

- Lyle, op. cit., p. 192-93. teaching faculty"; and "faculty rank for all, but as administrators."

In examining the issue of sabbatical leaves for librarians, it should be noted that because of a typing error only twenty-two library directors, heading the largest libraries, were questioned on this subject. Since sabbatical leaves for librarians, and often for the teaching faculty, especially in smaller schools, are of relatively recent origin, it is remarkable that professional librarians at four (18 per cent) colleges or universities in the study are entitled to sabbatical leaves, and one additional institution grants such leaves only to the library director. Of institutions granting leaves, one librarian reported that leaves are not granted at regular intervals. The directors of libraries where sabbatical leaves are not granted supplied such comments as "sabbatical leaves are under negotiation now"; "not yet for librarians"; "the teaching faculty sabbaticals start in 1966/67, for librarians not yet"; "no precedent has been set; no policy."

The subject of librarians' salaries was the last substantive question in the survey of the fifty-six Catholic college and university libraries. According to the ALA's Standards for College Libraries, "the salary schedule for librarians should be the same as for teaching members of the faculty."10 Given two options in the questionnaire, (1) "the salaries of librarians are less than the salaries of the teaching faculty," and (2) "the salaries are approximately the same as the salaries of the teaching faculty," twelve respondents ( 22 per cent) answered yes to the first statement and thirty-two of the library directors (60 per cent) said yes to the second statement. Eight (15 per cent) indicated that the salaries were the same as for teachers. One librarian (1.8 per cent) stated that the

10 "Standards for College Libraries," $C R L, \mathrm{XX}$ (July 1959), 276. 
salaries were possibly higher. Of fiftysix respondents, three either did not answer the question or said that the salaries were impossible to equate. Thus the percentages indicated above are based on fifty-three institutions.

Many comments were made on the subject of salaries. Here are some from librarians who stated that salaries are the same for librarians and teachers: "Our professionals have the same rules, exactly, as the teaching faculty. Their promotion, tenure, etc. are identical. However, since teaching faculty is paid on ten months basis, and the library faculty on a twelve months basis, there is an obvious difference in salaries. Proportionately, however, they are about equal." Somewhat similar is the comment of the next librarian who said "the same ... but librarians have about seven weeks vacation, while teachers have twelve weeks." Another librarian commented that "graduates of library schools are appointed with rank of instructor and salary [is] that of beginning instructor." Regarding the percentage increase of salaries, one librarian stated that "salaries are the same ... with the same percentage increase, because of more exacting schedules and summer employment." Finally, in a library where librarians' services are contributed, the corresponding estimate for salaries is the same as for teaching. From the institutions where librarians' salaries are only approximately the same as those of the teaching faculty, various explanations can also be cited: "The salaries are slightly lower," said one library director, "and the teaching faculty can supplement the income by teaching summer courses, while librarians are all on eleven-month contracts." About the same reasoning is evident in this comment: "The salary is annual instead of for nine months." One director said that in some cases the salaries are higher than the faculty salaries in the same rank. Only two comments were given by respondents from institutions which reported librar- ians' salaries to be lower than teachers' salaries. The first one stated "not much less," and the second commented "ninety per cent of equivalent."

\section{Conclusion}

Several significant observations and conclusions can be derived from this study. Judging from the large number of libraries where professional librarians help the director to make decisions and to solve problems, and contribute suggestions for better management of the libraries, we may well conclude that most colleges and universities in this study adhere to the democratic form of library administration. This attitude of sharing authority seems to be in keeping with the modern trends. Another interesting observation resulting from the study is the fact that sabbatical leaves, only recently granted to some individuals in the library profession, are now established at 18 per cent of the libraries queried on the subject. Similarly, the prediction that head librarians in college and university libraries will in future receive the status of dean is already reality in nine per cent of institutions participating in this study. Further, the number of nonprofessional staff members has increased at most of the schools in the study, giving the professional librarian, supported by additional clerical help, much more time to devote to professional duties.

The reader can make a number of additional comparisons and observations, some encouraging and some discouraging, from the data in the study. It should be noted, however, that this study involves Catholic colleges and universities of a certain size only, and thus provides to a large extent in-group comparisons or comparisons of this group of colleges to various standards. A broader study, involving perhaps the same number of similar institutions, but with different administrative outlook and financial support, would provide a much broader picture of librarians' involvement in higher education. 